\title{
Product Attributes and Price on Purchase Decision of Xiaomi Smartphone
}

\author{
Adhitama Satyanegara \\ Major of Business Administration, \\ Faculty of Communication and Business, Telkom University \\ adhitamasty@students.telkomuniversity.ac.id \\ Cut Irna Setiawati \\ Major of Business Administration, \\ Faculty of Communication and Business, Telkom University
}

\begin{abstract}
The aim of this study is to determine how the influence of product attributes and price on purchase decisions partially or simultaneously. This study used a sample of 100 respondents who are users of Xiaomi smartphones in Bandung, Jakarta, and Depok. Data analysis technique used in this study is descriptive analysis and multiple linear regression. Product attributes and price partially give positive and significant impact on purchasing decisions. Simultaneously, product attributes and price significantly give influence on purchasing decisions by $42.2 \%$. It can be concluded that either partial or simultaneous attributes of the product and the price have significant impact on product purchasing decisions of Xiaomi smartphone.
\end{abstract}

Keywords: product attributes, price, purchase decision, Xiaomi.

\section{INTRODUCTION}

One of people's needs in experiencing significant development in this globalization era is technology and communication. The needs cause to the increasing demand for various types of technology and telecommunications devices, such as smartphones. These are due to the consumption patterns of consumers today who always want the ease and speed of communication and support their daily activities. Therefore the consumers' choices to use the smartphone are now very diverse, one of which is a branded product of Xiaomi smartphone.

Xiaomi smartphone products can be consumers' choices and Xiaomi is currently experiencing a very high increase in the level of sales in the world smartphone market share. This can be seen more clearly in the Table 1.

Based on this Table 1, about 1.16 billion units of smartphones were sold in 2014, increasing by 25.9 percent from a year earlier. Samsung still holds the number one in smartphone sales. Samsung was managed to sell 326.4 million units of smartphones in 2014.

From Table 1, it can also be seen that Xiaomi which in 2013 did not enter the ranks of the top 10, in 2014 immediately had raced to sixth with a market share of 5.2 percent. Even in $2015 \mathrm{Xiaomi}$ was predicted to be
Table 1. World Smartphone Market Share In 2014

\begin{tabular}{|c|c|c|c|c|c|c|}
\hline Rankings & $\begin{array}{c}2013 \\
\text { Company }\end{array}$ & $\begin{array}{l}\text { Market } \\
\text { Share }\end{array}$ & $\begin{array}{c}2014 \\
\text { Company }\end{array}$ & $\begin{array}{l}\text { Market } \\
\text { Share }\end{array}$ & $\begin{array}{c}2015 \\
\text { Company }\end{array}$ & $\begin{array}{c}\text { Market } \\
\text { Share } \\
\text { (F) }\end{array}$ \\
\hline 1 & Samsung & $32,5 \%$ & Samsung & $28,0 \%$ & Samsung & $26,6 \%$ \\
\hline 2 & Apple & $16,6 \%$ & Apple & $16,4 \%$ & Apple & $16,4 \%$ \\
\hline 3 & Lenovo & $4,9 \%$ & $\begin{array}{l}\text { Lenovo }+ \\
\text { Motorola }\end{array}$ & $7,9 \%$ & Lenovo & $7,4 \%$ \\
\hline 4 & Huawei & $4,4 \%$ & LG & $6,0 \%$ & Huawei & $6,6 \%$ \\
\hline 5 & LG & $4,3 \%$ & Huawei & $5,9 \%$ & Xiaomi & $6,5 \%$ \\
\hline 6 & Sony & $4,1 \%$ & Xiaomi & $5,2 \%$ & LG & $6,1 \%$ \\
\hline 7 & Coolpad & $3,6 \%$ & Coolpad & $4,2 \%$ & TCL & $4,1 \%$ \\
\hline 8 & ZTE & $3,2 \%$ & Sony & $3,9 \%$ & Coolpad & $4,0 \%$ \\
\hline 9 & Nokia & $3.0 \%$ & ZTE & $3,1 \%$ & ZTE & $3,4 \%$ \\
\hline 10 & RIM & $2,5 \%$ & TCL & $2,7 \%$ & Sony & $3,1 \%$ \\
\hline & Others & $20.9 \%$ & Others & $16,7 \%$ & Others & $15,8 \%$ \\
\hline Shipment & \multirow{2}{*}{\multicolumn{2}{|c|}{927,2}} & \multirow{2}{*}{\multicolumn{2}{|c|}{$1.166,9$}} & \multirow{2}{*}{\multicolumn{2}{|c|}{$1.290,3$}} \\
\hline $\begin{array}{c}\text { Total } \\
\text { (Unit:M) }\end{array}$ & & & & & & \\
\hline
\end{tabular}

capable to claim to the fifth with a market share of 6.5 percent. The projection could be considered reasonable because total sales of Xiaomi increased significantly from year to year. In 2014, Xiaomi had sold 61.12 million units of smartphones, increased threefold from 
the previous year's sales figures (id.techinasia.com).

As a whole, for smartphone market share in Indonesia, Xiaomi is still not able to get into a great position in 5th and it can be seen in the Table $2 \& 3$.

Table 2. Indonesian Handset Market Share for the Year 2015

$\begin{array}{clrr}\text { Rank } & \text { Indonesia Handset Shipments } & \text { 4Q 2013 } & \text { 1Q 2014 } \\ & \text { Share (\%) } & 19,0 \% & 21,2 \% \\ 1 & \text { Samsung } & 18,2 \% & 18,2 \% \\ 2 & \text { Evercoss } & 15,6 \% & 10,9 \% \\ 3 & \text { Microsoft } & 7,3 \% & 8,5 \% \\ 4 & \text { Mito } & 7,8 \% & 6,7 \% \\ 5 & \text { Smartfren } & 32,1 \% & 34,5 \% \\ & \text { Others } & 100 \% & 100,0 \% \\ & \text { Total } & & \\ & \text { : } & & \end{array}$

Source : Noviandari (2015)

Table 3. Indonesian Smartphone Market Share for the Year 2015

\begin{tabular}{clrr} 
Rank & Indonesia Smartphone & $4 \mathrm{Q} 2014$ & $1 \mathrm{Q} 2015$ \\
& Shipments Share (\%) & $25,4 \%$ & $32,9 \%$ \\
\hline 1 & Samsung & $13,4 \%$ & $13,1 \%$ \\
3 & Evercoss & $15,4 \%$ & $12,9 \%$ \\
4 & Smartfren & $7,7 \%$ & $7,1 \%$ \\
5 & Oppon & $8,8 \%$ & $6,1 \%$ \\
& Others & $28,3 \%$ & $27,9 \%$ \\
& Total & $100 \%$ & $100,0 \%$
\end{tabular}

Source : Noviandari (2015)

This probably causes Xiaomi which rested with the online sales system and have not been so eager as to sell their production offline. For other offline product sales, Xiaomiinc. cooperated with Erajaya, where consumers can get Xiaomi products either in Oke Shop, Global Teleshop and Erafone outlets. It looks less good for Xiaomi itself because people do not always want to buy goods online.

Therefore the level of Xiaomi smartphone sales in Indonesia is still very low. It is not even able to get into the top 5 position when the product attributes and price offered by Xiaomi has been good. It is interesting matter to study for the authors and in fact it is much different from the conditions happening in global markets where Xiaomi smartphone sales level is high.

The effect of price on purchasing decisions is very important, because the price level set by the company can be measured for the demand of a product. According to Kotler and Armstrong (2012), the price is the amount charged on the products and services.

Consumer purchasing decisions explain how the consumer decides to buy something. The purchasing decision itself here is the selection of an act of two or more option alternatives (Schiffman and Kanuk, 2010; in Sumarwan, 2011). Xiaomi smartphone consumers would consider alternatives before making any purchasing decisions of products they buy.

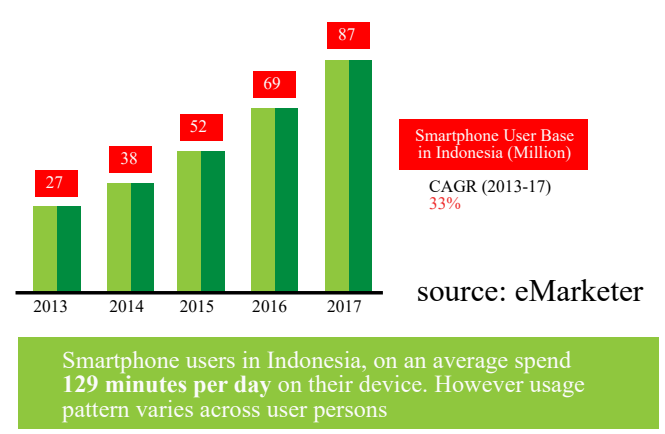

Figure 1. Smartphone Users in Indonesia

In this research, authors examined the attribute variables of Xiaomi smartphone products comprising from the quality, features, style and design, guarantee, complementary services, and resonable variable expected to support the success of this research.

The reasons for choosing research sitesnamely in of Bandung, Jakarta, and Depok, because the development of the number of smartphone users in Indonesia is quite rapid from year to year as shown in the figure above. It can be represented by the cities chosen because the people in big cities have more advanced and enjoyed a rapid development of technology and telecommunications today. People in those cities also now have a modern lifestyle and always updated of technology and telecommunications development.

\section{METHOD}

This type of research is causal descriptive. This research is classified into quantitative research that uses numbers and analyzed by using statistical method. Descriptive research is research with regard to the question on independent variable, either only on one or more variables. The causal relationship is a relationship that is both cause and effect, where there are variables that influence and variables that are influenced (Sugiyono, 2012).

Research framework is made to facilitate the making and analyzing the research hypothesis, Figure 2

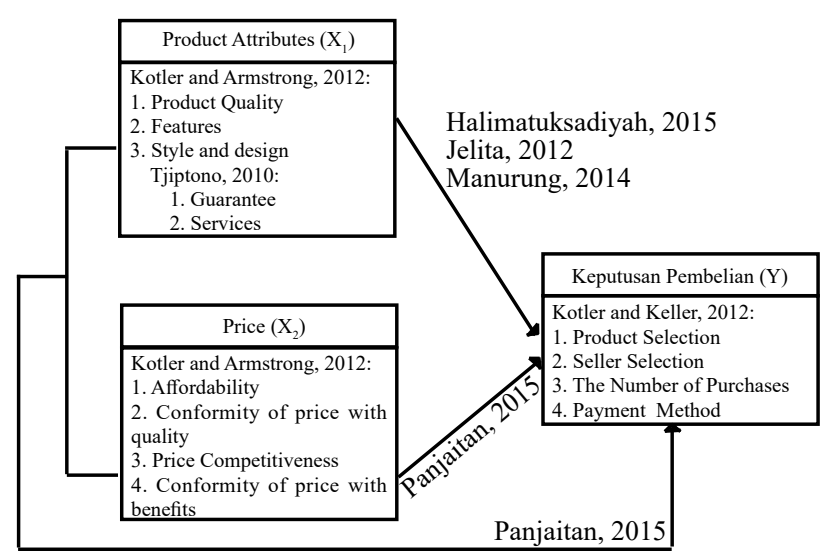

Figure 2. Research Framework 
The hypothesis proposed in this research is product attributes and price influence on purchase decisions of Xiaomi Smartphone products," simultaneously and partially. Samples are 100 respondents with purposive sampling technique, that is the user of Xiaomi Smartphone located in Bandung (32) respondent, Jakarta (45) respondent, and Depok (23) respondent.

The validity and reliability of collected data will be further tested with a significance level of 0.05 . Validity test can be done by comparing the value of $r$ count with $r$ table. If $r_{\text {count }}>r_{\text {table }}$ and has positive value, then the statement is said to be valid (Sugiyono, 2008). Reliability test used Cronbach Alpha statistical test, namely a variable is said to be reliable if $>0.70$ (Ghozali, 2011).

Descriptive statistics are used to analyze data without intending to apply to general conclusions or generalizations (Sugiyono, 2012).

Multiple linear regression analysis is used to measure effect between two or more independent variables to predict dependent variable. Multiple regression models are shown as follows.

Description:

$$
\mathrm{Y}=\mathrm{a}+\mathrm{b}_{1} \mathrm{X}_{1}+\mathrm{b}_{2} \mathrm{X}_{2}+\mathrm{e}
$$

$\mathrm{Y}$ : the purchasing decision

a : constant

$\mathrm{b}_{1}$ : multiple regression co-efficient between $\mathrm{x}_{1}$ and $\mathrm{y}$

$b_{2}$ : multiple regression co-efficient between $x_{2}$ and $y$

$\mathrm{e}$ : error

$\mathrm{X}_{1}$ : product attributes

$\mathrm{X}_{2}$ : price

1. T test (Partial), T statistical test shows how far the effect of the independent variable on the dependent variable (Ghozali, 2011). In this case applies, $\mathrm{t}<\mathrm{t}$ table, then $\mathrm{H}_{0}$ is accepted $\left(\mathrm{H}_{1}\right.$ is rejected), and if $\mathrm{t}>\mathrm{t}$ table, then $\mathrm{H}_{0}$ is rejected $\left(\mathrm{H}_{1}\right.$ is accepted $)$ on $=0.05$.

2. F Test (Simultaneous), F statistical test basically indicates whether all the independent variables included in the model have effect together to the dependent variable (Ghozali, 2011). In this case applies, if $\mathrm{F}$ count $<\mathrm{F}$ table, then $\mathrm{H}_{0}$ is accepted $\left(\mathrm{H}_{1}\right.$ is rejected $)$, and if $\mathrm{F}$ count $<\mathrm{F}$ table, then $\mathrm{H}_{0}$ is rejected $\left(\mathrm{H}_{1}\right.$ is accepted $)$.

3. Determination coefficient $\left(\mathrm{R}^{2}\right)$ essentially measures how far the ability of the model to explain variations in the dependent variable. If $\mathrm{R}^{2}$ value is small, it means that the ability of the independent variables in explaining the dependent variable is very limited.

\section{RESULT}

Based on the validity test results, of such distribution showed that all statements are valid, because $r$ count $>$ $r$ table (Sugiyono, 2012). Likewise, the reliability test results showed that all statements are reliable because the coefficient is $>0.70$ (Ghozali, 2011).

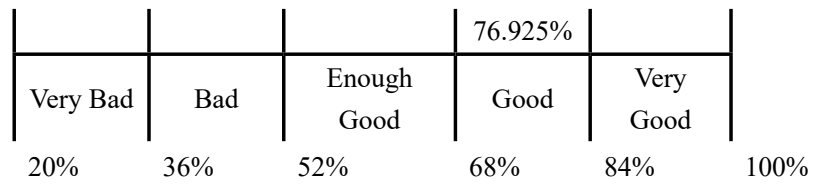

Figure 5. Respondent Responses to Product Attributes $\left(\mathrm{X}_{1}\right)$

\section{a. Product Attribute Variable $\left(\mathrm{X}_{1}\right)$}

Average score for total of 12 items from the product attribute variables $\left(X_{1}\right)$ generates a figure of $76925 \%$, which means that the score is in good category. This shows Xiaomi product attribute variables $\left(X_{1}\right)$ with sub variables of quality, features, style and design, guarantee/warranty, as well as complementary services can be received by the respondents well.

\begin{tabular}{|c|c|c|c|c|}
\hline & & & & $87.85 \%$ \\
\hline Very Bad & $\mathrm{Bad}$ & $\begin{array}{c}\text { Enough } \\
\text { Good }\end{array}$ & Good & Very Good \\
\hline $20 \%$ & $36 \%$ & $52 \%$ & $68 \%$ & $84 \%$ \\
\hline
\end{tabular}

\section{b. Price Variable $\left(\mathrm{X}_{2}\right)$}

Average score for total of four items from the price variable $\left(\mathrm{X}_{2}\right)$ generate a figure of $87.85 \%$, which means that the scores are in very good category. This indicates that the price variable $\left(\mathrm{X}_{2}\right)$ with sub variables of affordability, conformity price with quality, price competitiveness, as well as conformity of price with benefits, can be obtained by respondents very well.

\begin{tabular}{|c|c|c|c|c|c|} 
& & & & $85.05 \%$ & \\
\hline $\begin{array}{c}\text { Very } \\
\text { Bad }\end{array}$ & Bad & $\begin{array}{c}\text { Enough } \\
\text { Good }\end{array}$ & Good & $\begin{array}{c}\text { Very } \\
\text { Good }\end{array}$ & \\
$20 \%$ & $36 \%$ & $52 \%$ & $68 \%$ & $84 \%$ & $100 \%$
\end{tabular}

Figure 7. Respondent Response to the Purchase Decision (Y)

\section{c. Purchasing Decision Variable (Y)}

Average score for total of 4 items from purchase decision variable (Y) generates a figure of $85.05 \%$, which means that the scores are in very good category. This suggests consumers to make purchasing decisions very well with the existing consideration and alternatives or options.

Based on the result data of regression, a regression equation can be obtained as followed:

$$
\mathrm{Y}=0.642+0.370 \mathrm{X}_{1}+0.501 \mathrm{X}_{2}+\mathrm{e}
$$

a. Constant of 0.642 means that if two independent variables $\left(\mathrm{X}_{1}, \mathrm{X}_{2}\right)$ are zero and there is no change, then the purchase decision is valued of 0.642 . 
b. Coefficient of $X_{1}=0.370$ means that if the product attribute variable affect positively on purchase decisions of Xiaomi smartphone product, or in other words if the product attribute variable is increased by one unit then the purchase decisions of Xiaomi smartphone product will increase by 0.370 .

c. Coefficient of $X_{2}=0.501$ means that if the price variable has positive effect on purchase decisions of Xiaomi smartphone product, or in other words if the price variable is increased by one unit then the purchase decision of Xiaomi smartphone product will increase by 0.501 .

Table 5. Multiple Linear Regression Analysis Coefficients ${ }^{\mathrm{a}}$

\begin{tabular}{|c|c|c|c|c|c|}
\hline \multirow{3}{*}{ Model } & \multirow{2}{*}{\multicolumn{2}{|c|}{$\begin{array}{c}\text { unstandardized } \\
\text { Coefficients }\end{array}$}} & \multirow{2}{*}{$\frac{\text { Standardized }}{\text { Coefficients }}$} & \multirow{3}{*}{$\mathrm{t}$} & \multirow{3}{*}{ sig. } \\
\hline & & & & & \\
\hline & B & $\begin{array}{l}\text { Std. } \\
\text { Error }\end{array}$ & Beta & & \\
\hline 1 (constant) & .642 & .435 & & 1.474 & .144 \\
\hline $\begin{array}{l}\text { product } \\
\text { attributes }\end{array}$ & .370 & .105 & .317 & 3.511 & .001 \\
\hline price & .501 & .106 & .426 & 4.712 & .000 \\
\hline
\end{tabular}

a. Dependent Variable: Purchase Decision

Table 6. Model Summary

\begin{tabular}{ccccc}
\hline Model & $\mathrm{R}$ & R Square & $\begin{array}{c}\text { Adjusted } \\
\text { R Square }\end{array}$ & $\begin{array}{c}\text { Std. Error } \\
\text { of the } \\
\text { Estimate }\end{array}$ \\
\hline 1 & $.650^{\mathrm{a}}$ & .422 & .410 & .47256 \\
\hline a. Predictors: (Constant), Price, Product Attributes &
\end{tabular}

1. T count value in the product attribute variable $\left(X_{1}\right)$ is 3.511 and $t$ table value is 1,984 . The significant value on the t count table is 0.001 and less than 0.05 . Because $3.511>1.984$ and $0.001<0.05$ and then $\mathrm{H} 0$ and $\mathrm{H} 1$ are accepted. Product attribute variable $\left(\mathrm{X}_{1}\right)$ has calculation results of 0.37 , which means the variable has a partial effect by $37 \%$.

2. . T count value at the price variable $\left(\mathrm{X}_{2}\right)$ is 4.712 and $t$ table value is 1.984 . The significant value on the $t$ count table is 0.000 and less than 0.05 . Because $3.511>1.984$ and $0.000<0.05$, and then $\mathrm{H} 0$ is rejected and $\mathrm{H} 1$ is received. Price variable $\left(\mathrm{X}_{2}\right)$ has a count result of 0.501 which means that this variable has a partial effect of $50.1 \%$.

Table 7. F Test (Simultaneous) ANOVA ${ }^{\mathrm{b}}$

\begin{tabular}{lccccc}
\hline \multicolumn{1}{c}{ Model } & $\begin{array}{c}\text { Sum of } \\
\text { Squares }\end{array}$ & df & $\begin{array}{c}\text { Mean } \\
\text { Square }\end{array}$ & F & Sig. \\
\hline 1. Regression & 15.841 & 2 & 7.920 & 35.467 & $.000^{\mathrm{a}}$ \\
Residual & 21.662 & 97 & .223 & & \\
Total & 37.503 & 99 & & & \\
\hline
\end{tabular}

a. Predictors: (Constant), Price, Product Attributes

b. Dependent Variable: Purchase Decision
Based on the table it can be seen that $\mathrm{F}$ count $=$ 35.467 , so that it meets the criteria that $\mathrm{H}_{1}$ is accepted if F count (35.467) $>$ F table (3.09) and the Sig. value of $0.000<0.05$. This means that the product attributes and price simultaneously have positive and significant effect on purchasing decision of Xiaomi smartphone products.

$\mathrm{R}=0.650$ means that the relationship between the product attribute variable and price on purchasing decisions of Xiaomi smartphone product is $65 \%$ and the remaining is $35 \%$ influenced by factors other than not examined in this research. R Square of 0.422 means that $42.2 \%$ purchasing decision variable can be explained by the product attribute and the price while the remaining is explained by variables other than not examined in the research.

Average total score of 12 items from the product attribute variables $\left(\mathrm{X}_{1}\right)$ is $76,925 \%$, which means that the scores are in good category. This shows product attribute variables of Xiaomi $\left(\mathrm{X}_{1}\right)$ with sub variables of quality, features, style and design, warranty, or complementary services can be received by the respondents well.

Average total score of four items from the price variable $\left(\mathrm{X}_{2}\right)$ generate a figure of $87.85 \%$, which means that this score is categorized as very good. This indicates that the price variable $\left(\mathrm{X}_{2}\right)$ with sub variables of affordability, suitability price with quality, competitive price, as well as conformity of price with benefits, can be obtained by respondents very well.

Average score for total of 4 items from purchasing decision variable $(\mathrm{Y})$ generates a figure of $85.05 \%$, which means that the scores are in very good category. This shows the purchasing decision variable (Y) with sub variable of product selection, seller selection, purchase amount and payment method, can be received by respondents very well.

Partial effect by using t test, can be explained for each variables as follows:

a. Product Attribute Variable $\left(\mathrm{X}_{1}\right)$

Based on the multiple linear regression analysis results, the product attribute variable value $\left(\mathrm{X}_{1}\right)$ obtained is 0.37 or $37 \%$. T test results obtained that product attribute variable $\left(\mathrm{X}_{1}\right)$ has a significant effect on purchasing decisions (Y) of Xiaomi smartphone product, it can be seen from the smaller significant value than the (alpha) value, namely $0.001<0.05$ then $\mathrm{H}_{0}$ and $\mathrm{H}_{1}$ are accepted. Therefore, it can be concluded that the product attribute variable $\left(\mathrm{X}_{1}\right)$ has significant effect on purchasing decisions $(\mathrm{Y})$ of Xiaomi smartphone products. b. Price Variable $\left(\mathrm{X}_{2}\right)$

Based on the multiple linear regression analysis, the price variable value $\left(\mathrm{X}_{2}\right)$ obtained is 0501 , or $50.1 \%$. $\mathrm{T}$ test results obtained that the price variable $\left(\mathrm{X}_{2}\right)$ has a significant effect on purchasing decisions (Y) of Xiaomi smartphone product, it can be seen from the smaller significant value than the (Alpha) value used namely $0.000<0.05$ then $\mathrm{H} 0$ and $\mathrm{H} 1$ are accepted. So 
it can be concluded that the product attribute variable $\left(\mathrm{X}_{1}\right)$ has significant effect on purchasing decisions $(\mathrm{Y})$ of Xiaomi smartphone products.

The conclusion from these results is that partially, product attributes $\left(\mathrm{X}_{1}\right)$ has a significant efffect on purchasing decisions of Xiaomi smartphone product $(\mathrm{Y})$ and the price $\left(\mathrm{X}_{2}\right)$ also has a significant effect on purchasing decisions of Xiaomi smartphone product $(\mathrm{Y})$.

Research that have been carried out also proved that there is a positive relationship between product attributes and price with the purchasing decision. In the study conducted by (Manurung, 2014) who examined the Effect of Product Attribute on Purchasing Decision of Blackberry Smartphone at Faculty of Economics, University of North Sumatera, she indicated that there is a positive and significant relationship between product attributes with purchasing decision. The study made by Jelita (2012) with the title of The Effect of Consumer Perception regarding Product Attributes on Purchasing Decision of Blackberry Smartphone in Hasanuddin University, Makassar, proved that the product attributes has positive relationship with purchasing decisions.

In this research, the independent variable used is product attribute variable $\left(\mathrm{X}_{1}\right)$ and the price $\left(\mathrm{X}_{2}\right)$ and the dependent variable used is the purchasing decision $(\mathrm{Y})$. Based on the calculation, the determination coefficient $\left(R^{2}\right)$ indicates the value of $r=0.650$, which means the relationship between independent variables (product attribute and price) on the dependent variable (purchasing decisions) is $65 \%$ positive and closely (Situmorang and Lutfi, in Panjaitan, 2015).

R Square $=0.422$ means that $42.2 \%$ of purchasing decisions may be influenced by the independent variable (product attributes and prices) while the remaining $57.8 \%$ is influenced by other variables which arenot examined in this research. To determine the simultaneous relationship with product attribute variables $\left(\mathrm{X}_{1}\right)$ and the price $\left(\mathrm{X}_{2}\right)$ on purchasing decisions $(\mathrm{Y})$ it can be shown at the F-test value, namely F significance value (Sig.) of the study results is 0.000 while the (Alpha) value is 0.05 , $0.000<0.05$ and $\mathrm{F}$ count value $=35467$, therefore it meets the criteria that $\mathrm{H}_{1}$ is accepted if $\mathrm{F}$ count (35.467) $>$ F table (3.09) and the Sig. $0.000<0.05$. Product attributes and price have simultaneously positive and significant effect on purchasing decisions of Xiaomi smartphone products.

This is supported by research conducted by Panjaitan (2015) he concluded that test product attributes, prices, and brand image simultaneously have positive and significantly effects the purchasing decisions of consumers on I-phone Apple Store of Sun Plaza Medan. Hypothesis test result simultaneously proved that if attribute and price offered by a product has been running well, consumers will get the benefit from a product to the maximum and the price imposition invoiced to a product in this case Xiaomi smartphone has been appropriate to do (Kotler and Armstrong, 2012). Consumers will consider the product attributes and the price offered as an alternative in making a purchasing decision (Kotler and Keller, 2012).

\section{CONCLUSION}

Based on the research that has been observed, the authors conclude as follows:

1. Average total score of 12 items from product attribute variable generates a figure of $76.925 \%$ is in good category. This indicates that the product attributes of Xiaomi smartphone can be received by the respondents well.

2. Average total score of 4 items from price variables generates a figure of $87.85 \%$ is in the very good category. This indicates that the price of Xiaomi smartphones can be received by the respondents very well in keeping with the wishes of consumers.

3. Average total score of 4 items from purchasing decision variable generates a figure of $85.05 \%$, is in the very good category. This shows that consumers are taking purchasing decisions very well and considering various options or alternatives.

4. Product attributes partially has a positive and significant effect on purchasing decisions of Xiaomi smartphone product. The price also partially has positive and significant effect on purchasing decisions of Xiaomi smartphone product.

5. Product attributes and price simultaneously has positive and significant effect on purchasing decisions of Xiaomi smartphone product of $42.2 \%$ while the remaining $57.8 \%$ is influenced by other variables which are not examined in this research.

\section{REFERENCE}

Ghozali, Imam. 2011. Aplikasi Analisis Multivariate dengan program IBM SPSS 19.Semarang: Universitas Diponegoro.

Halimatuksadiyah. 2015. Analisis Pengaruh Atribut Produk dan Sikap Konsumen terhadap Keputusan Pembelian Produk Luwak White Coffe pada Mahasiswa Fakultas Teknik Universitas Sumatera Utara. Medan: Universitas Sumatera Utara. http:// repository.usu.ac.id

Jelita, Putri,Charly.2012.Pengaruh Persepsi Atribut Produk terhadap Keputusan Pembelian Handphone Merek Blackberry di Universitas Hasanuddin. Skripsi. Makassar: Universitas Hasanuddin.

Kotler, Philip \& Armstrong, Gary. 2012. Principles of Marketing. England: Pearson Education Limited.

Kotler, Philip \& Keller, Kevin Lane. 2012. Marketing Management. England: Pearson Education Limited. Manurung, Handayanti, Kristina. 2014. Analisis Pengaruh Atribut Produk terhadap Keputusan 
Pembelian Blackberry pada Mahasiswa Fakultas Ekonomi Universitas Sumatera Utara. Skripsi. Medan: Universitas Sumatera Utara. http:// repository.usu.ac.id

Noviandari, Lina. 2015. 1,16 miliar smartphone dikirimkan di 2014, pangsa pasar Samsung dan Apple turun. Access in 9th Januari 2016, from https://id.techinasia.com/jumlah-penjualansmartphone-2014

Noviandari, Lina. 2015. Samsung Masih Kuasai Pasar Ponsel Indonesia di Q1 2015, Evercoss Nomor Dua. Access in 9th Januari 2016, from https:// id.techinasia.com/pasar-ponsel-dan-smartphoneindonesia-q1-2015/

Panjaitan, Suryanti, Jessi. 2015. Analisis Pengaruh
Atribut Produk, Harga, dan Brand Image terhadap Keputusan Pembelian IPhone pada Konsumen di Apple Store Sun Plaza Medan. Medan: Universitas Sumatera Utara. http://repository.usu.ac.id Sugiyono, 2012. Metode Penelitian Kuantitatif Kualitatif dan $R \& D$. Bandung: Alfabeta.

Sumarwan, Ujang. 2011. Perilaku Konsumen: Teori dan Penerapannya dalam Pemasaran. Bogor: Ghalia Indonesia.

Tjiptono, Fandy. 2010. Strategi Pemasaran. Edisi 3. Yogyakarta: Andi.

Websites:

www.vserv.com/vserv-unveils-first-smartphone-userpersona-report-supr indonesia/

[access in 21st Februari dan 1st April 2016]

\section{APPENDIX}

\section{SCREENING}

Circle the answers on the appropriate option Q1. Do you knowXiaomi Smartphone Product?

1. Yes. (next question please)

2. No. (thank you for participation)

Q2. Do you buy/use Xiaomi Smartphone Product?

1. Yes. (next question please)

2. No. (thank you for participation)

Q3. Where do you live?
1 . Bandung.
3. Depok.
2. Jakarta.

I. Respondents identity.

Circle the answers on the appropriate option

1. Gender:
a). Male.
b). Female.

2. Age
a). $<20$ y.o.
c). $30-40$ y.o.
b). 20-30 y.o.
d). $>40$ y.o.

3. Highest Education.
a). ES/JHS.
c). Diploma/B. Degree.
b). SHS.
d). Master Degree/higher.

4. Job.
a). Student/College.
c). Civil Servants.
b). Employees.
d). Entrepreneur.

5. Income /mo. (IDR)
a). $1.000 .000-2.000 .000$
b). $2.000 .000-3.000 .000$
c). $3.000 .000-4.000 .000$
d). $>4.000 .000$

II. Filling instructions.

Criteria :

Strongly Agree (SA) : 5

Agree (A) $\quad: 4$

Simply Agree (Si.A) : 3

Disagree (D) : 2

Strongly Disagree (SD) $\quad: 1$

Respondent Characteristics

a. Location

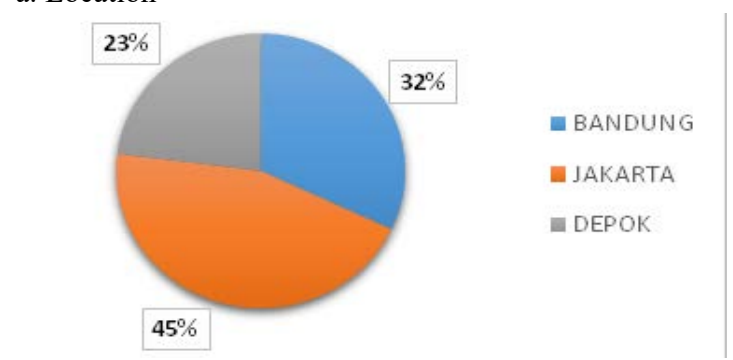

b. Gender
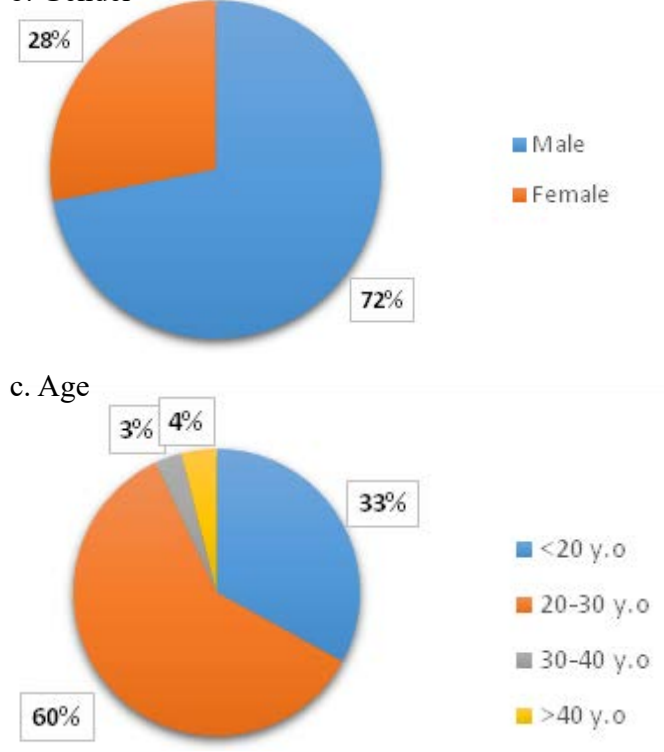
d. Highest Education
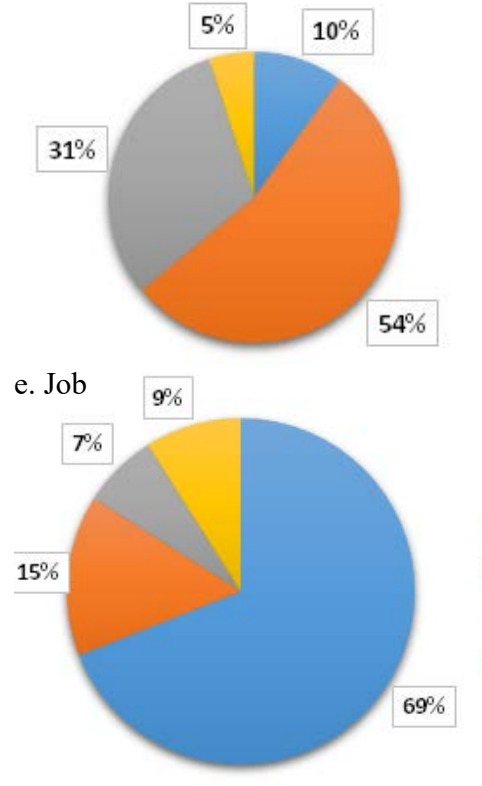

f. Income

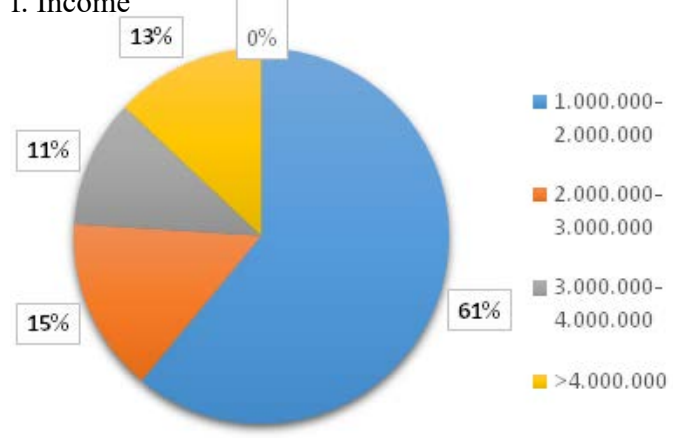

- Student/College

Employees

a Civil Servants

Entrepreneur

Descriptive Responden Analysist

Respondents Against Product Attributes Variables $\left(\mathrm{X}_{1}\right)$

\begin{tabular}{|c|c|c|c|c|c|c|c|c|c|}
\hline \multirow{2}{*}{ No } & \multirow{2}{*}{ Items } & \multicolumn{5}{|c|}{ Respondents } & \multirow{2}{*}{ Sum } & \multirow{2}{*}{$\begin{array}{l}\text { Total } \\
\text { Score }\end{array}$} & \multirow{2}{*}{$\begin{array}{l}\text { Ideal } \\
\text { Score }\end{array}$} \\
\hline & & $\mathbf{S A}$ & $\mathbf{A}$ & Si.A & D & SD & & & \\
\hline \multirow{2}{*}{1} & \multirow{2}{*}{$\begin{array}{l}\text { Xiaomi smartphone product has the durability and good } \\
\text { quality }\end{array}$} & 27 & 53 & 20 & 0 & 0 & 100 & 407 & 500 \\
\hline & & $27 \%$ & $53 \%$ & $20 \%$ & 0 & 0 & $100 \%$ & $81.4 \%$ & \\
\hline \multirow{2}{*}{2} & \multirow{2}{*}{$\begin{array}{l}\text { Xiaomi smartphone product has excellent product } \\
\text { performance (not often hang and fast heat) }\end{array}$} & 33 & 51 & 15 & 1 & 0 & 100 & 416 & 500 \\
\hline & & $33 \%$ & $51 \%$ & $15 \%$ & $1 \%$ & 0 & $100 \%$ & $83.2 \%$ & \\
\hline \multirow{2}{*}{3} & \multirow{2}{*}{$\begin{array}{l}\text { Xiaomi smartphone product easy to repair in case of } \\
\text { damage(availability of spareparts, etc.) }\end{array}$} & 17 & 37 & 31 & 15 & 0 & 100 & 326 & 500 \\
\hline & & $17 \%$ & $37 \%$ & $31 \%$ & $15 \%$ & 0 & $100 \%$ & $62.5 \%$ & \\
\hline \multirow{2}{*}{4} & \multirow{2}{*}{$\begin{array}{l}\text { Xiaomi smartphone product features M1UI system interface } \\
\text { (see menu) interesting }\end{array}$} & 48 & 43 & 8 & 1 & 0 & 100 & 438 & 500 \\
\hline & & $48 \%$ & $43 \%$ & $8 \%$ & $1 \%$ & 0 & $100 \%$ & $87.6 \%$ & \\
\hline \multirow{2}{*}{5} & \multirow{2}{*}{$\begin{array}{l}\text { Xiaomi smartphone product has a characteristic that is } \\
\text { different from competitors }\end{array}$} & 44 & 34 & 18 & 3 & 1 & 100 & 417 & 500 \\
\hline & & $44 \%$ & $34 \%$ & $18 \%$ & $3 \%$ & $1 \%$ & $100 \%$ & $83.4 \%$ & \\
\hline \multirow{2}{*}{6} & \multirow{2}{*}{ Xiaomi smartphone product has a slim model } & 34 & 46 & 15 & 2 & 3 & 100 & 406 & 500 \\
\hline & & $34 \%$ & $46 \%$ & $15 \%$ & $2 \%$ & $3 \%$ & $100 \%$ & $81.2 \%$ & \\
\hline \multirow{2}{*}{7} & \multirow{2}{*}{ Xiaomi smartphone product has a shape that fits the hand } & 29 & 46 & 22 & 2 & 1 & 100 & 400 & 500 \\
\hline & & $29 \%$ & $46 \%$ & $22 \%$ & $2 \%$ & $1 \%$ & $100 \%$ & $80 \%$ & \\
\hline \multirow{2}{*}{8} & \multirow{2}{*}{$\begin{array}{l}\text { Xiaomi smartphone product comfortable to grip so easy to } \\
\text { use }\end{array}$} & 28 & 50 & 19 & 3 & 0 & 100 & 403 & 500 \\
\hline & & $28 \%$ & $50 \%$ & $19 \%$ & $3 \%$ & 0 & $100 \%$ & $80.6 \%$ & \\
\hline \multirow{2}{*}{9} & \multirow{2}{*}{$\begin{array}{l}\text { Xiaomi smartphone products have a warranty/guarantee that } \\
\text { reliable }\end{array}$} & 22 & 36 & 30 & 10 & 2 & 100 & 366 & 500 \\
\hline & & $22 \%$ & $36 \%$ & $30 \%$ & $10 \%$ & $2 \%$ & $100 \%$ & $73.2 \%$ & \\
\hline \multirow{2}{*}{10} & \multirow{2}{*}{$\begin{array}{l}\text { Easy claims guarantee/warranty products of Xiaomi } \\
\text { smartphone }\end{array}$} & 12 & 39 & 37 & 10 & 2 & 100 & 349 & 500 \\
\hline & & $12 \%$ & $39 \%$ & $37 \%$ & $10 \%$ & $2 \%$ & $100 \%$ & $69.8 \%$ & \\
\hline \multirow{2}{*}{11} & \multirow{2}{*}{$\begin{array}{l}\text { Xiaomi smartphone products provide complementary } \\
\text { services such as call center for customer complaints }\end{array}$} & 16 & 41 & 29 & 10 & 4 & 100 & 355 & 500 \\
\hline & & $16 \%$ & $41 \%$ & $29 \%$ & $10 \%$ & $4 \%$ & $100 \%$ & $71 \%$ & \\
\hline \multirow{2}{*}{12} & \multirow{2}{*}{ Ease of access phone numbers for customer complaints } & 13 & 43 & 24 & 17 & 3 & 100 & 346 & 500 \\
\hline & & $13 \%$ & $43 \%$ & $24 \%$ & $17 \%$ & $3 \%$ & $100 \%$ & $69.2 \%$ & \\
\hline Tot: & 1 Score & & & & & & & & \\
\hline Ave & rage Total Score $(\%)$ & & & & & & & 76.9 & \\
\hline
\end{tabular}


Respondents Againts Price Variables $\left(\mathrm{X}_{2}\right)$

\begin{tabular}{|c|c|c|c|c|c|c|c|c|c|}
\hline \multirow{2}{*}{ No } & \multirow{2}{*}{ Items } & \multicolumn{5}{|c|}{ Respondents } & \multirow{2}{*}{ Sum } & \multirow{2}{*}{$\begin{array}{l}\text { Score } \\
\text { Total }\end{array}$} & \multirow{2}{*}{$\begin{array}{l}\text { Ideal } \\
\text { Score }\end{array}$} \\
\hline & & SA & $\mathbf{A}$ & Si. A & D & SD & & & \\
\hline \multirow[t]{2}{*}{13} & \multirow{2}{*}{$\begin{array}{l}\text { I think that the product price of Xiaomi smartphone is very } \\
\text { affordable }\end{array}$} & 62 & 28 & 10 & 0 & 0 & 100 & 452 & \multirow[t]{2}{*}{500} \\
\hline & & $62 \%$ & $28 \%$ & $10 \%$ & 0 & 0 & $100 \%$ & $90.4 \%$ & \\
\hline \multirow[t]{2}{*}{14} & \multirow{2}{*}{$\begin{array}{l}\text { I think Xiaomi smartphone product prices according to the } \\
\text { quality offered }\end{array}$} & 49 & 42 & 7 & 2 & 0 & 100 & 436 & \multirow[t]{2}{*}{500} \\
\hline & & $49 \%$ & $42 \%$ & $7 \%$ & $2 \%$ & 0 & $100 \%$ & $87.2 \%$ & \\
\hline \multirow[t]{2}{*}{15} & \multirow{2}{*}{$\begin{array}{l}\text { Xiaomi smartphone product prices are competitive with } \\
\text { the other }\end{array}$} & 51 & 42 & 6 & 1 & 0 & 100 & 442 & \multirow[t]{2}{*}{500} \\
\hline & & $51 \%$ & $42 \%$ & $6 \%$ & $1 \%$ & 0 & $100 \%$ & $88.4 \%$ & \\
\hline \multirow[t]{2}{*}{16} & \multirow{2}{*}{$\begin{array}{l}\text { I think Xiaomi smartphone products have more benefits } \\
\text { than the price has been paid }\end{array}$} & 38 & 51 & 11 & 0 & 0 & 100 & 427 & \multirow[t]{2}{*}{500} \\
\hline & & $38 \%$ & $51 \%$ & $11 \%$ & 0 & 0 & $100 \%$ & $85.4 \%$ & \\
\hline
\end{tabular}

Total Score

Average Total Score (\%)

$87.85 \%$

Respondents Against Purchase Decision Variables (Y)

\begin{tabular}{|c|c|c|c|c|c|c|c|c|c|}
\hline \multirow{2}{*}{ No } & \multirow{2}{*}{ Items } & \multicolumn{5}{|c|}{ Respondents } & \multirow{2}{*}{ Sum } & \multirow{2}{*}{$\begin{array}{l}\text { Score } \\
\text { Total }\end{array}$} & \multirow{2}{*}{$\begin{array}{l}\text { Ideal } \\
\text { Score }\end{array}$} \\
\hline & & $\mathbf{S A}$ & $\mathbf{A}$ & Si. A & $\mathbf{D}$ & SD & & & \\
\hline \multirow[t]{2}{*}{17} & \multirow{2}{*}{$\begin{array}{l}\text { I buy a Xiaomi smartphone products in accordance the } \\
\text { wants and needs. }\end{array}$} & 51 & 41 & 8 & 0 & 0 & 100 & 443 & 500 \\
\hline & & $51 \%$ & $41 \%$ & $8 \%$ & 0 & 0 & $100 \%$ & $88.6 \%$ & \\
\hline \multirow[t]{2}{*}{18} & \multirow[t]{2}{*}{ I purchased Xiaomi smartphone products in stores/online. } & 44 & 36 & 9 & 7 & 4 & 100 & 402 & 500 \\
\hline & & $44 \%$ & $36 \%$ & $9 \%$ & $7 \%$ & $4 \%$ & $100 \%$ & $80.4 \%$ & \\
\hline \multirow[t]{2}{*}{19} & \multirow{2}{*}{$\begin{array}{l}\text { I purchased the product Xiaomi smartphone with the number } \\
\text { as needed. }\end{array}$} & 49 & 41 & 9 & 1 & 0 & 100 & 437 & 500 \\
\hline & & $49 \%$ & $41 \%$ & $9 \%$ & $1 \%$ & 0 & $100 \%$ & $87.4 \%$ & \\
\hline \multirow[t]{2}{*}{20} & \multirow{2}{*}{$\begin{array}{l}\text { I purchased the product Xiaomi smartphone with the } \\
\text { payment method of cash / credit. }\end{array}$} & 43 & 43 & 9 & 3 & 2 & 100 & 419 & 500 \\
\hline & & $43 \%$ & $43 \%$ & $9 \%$ & $3 \%$ & $2 \%$ & $100 \%$ & $83.8 \%$ & \\
\hline \multicolumn{7}{|c|}{ Total Score } & & \multicolumn{2}{|c|}{1701} \\
\hline \multicolumn{7}{|c|}{ Average Total Score $(\%)$} & & \multicolumn{2}{|c|}{$85.05 \%$} \\
\hline
\end{tabular}

SA : Strongly Agree

A : Agree

SiA : Simply Agree

D : Disagree

SD : Strongly Disagree 